\title{
Reactivity of (Vicinal) Carbonyl Compounds with Urea
}

\author{
Jacobus A. W. Jong, ${ }^{\dagger, \| \odot ~ R o b e r t ~ S m a k m a n, ~}{ }^{\S}$ Marc-Etienne Moret, ${ }^{\ddagger}$ Marianne C. Verhaar, \\ Wim E. Hennink, ${ }^{\dagger}$ Karin G. F. Gerritsen," and Cornelus F. Van Nostrum ${ }^{*}{ }^{\dagger}$
}

${ }^{\dagger}$ Department of Pharmaceutics, Utrecht Institute for Pharmaceutical Sciences (UIPS) and ${ }^{\ddagger}$ Organic Chemistry and Catalysis, Debye Institute for Nanomaterials Science, Utrecht University, Universiteitsweg 99, 3584 CG Utrecht, The Netherlands

${ }^{\S}$ Innovista, Raadhuisstraat 1, 1393 NW Nigtevecht, The Netherlands

"Department of Nephrology and Hypertension, University Medical Centre Utrecht, Heidelberglaan 100, 3584 CX Utrecht, The Netherlands

\section{Supporting Information}

ABSTRACT: Urea removal from dialysate is the major obstacle in realization of a miniature dialysis device, based on continuous dialysate regeneration in a closed loop, used for the treatment of patients suffering from end-stage kidney disease. For the development of a polymeric urea sorbent, capable of removing urea from dialysate with high binding capacities and fast reaction kinetics, a systematic kinetic study was performed on the reactivity of urea with a library of low-molecular-

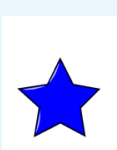

Carbonyl Compound

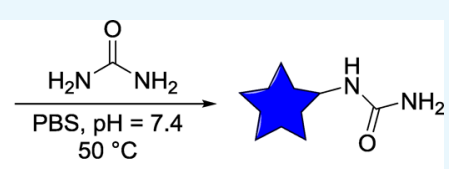

31 Examples $k=0.1-18.4 \mathrm{M}^{-1} \mathrm{~h}^{-1}$ weight carbonyl compounds in phosphate-buffered saline $(\mathrm{pH} 7.4)$ at $323 \mathrm{~K}$. It was

found that dialdehydes do not react with urea under these conditions but need to be activated under acidic conditions and require aldehyde groups in close proximity to each other to allow a reaction with urea. Among the 31 (hydrated) carbonyl compounds tested, triformylmethane, ninhydrin, and phenylglyoxaldehyde were the most reactive ones with urea. This is attributed to the low dehydration energies of these compounds, as calculated by Gibbs free energy differences between the hydrated and dehydrated carbonyl compounds, which are favorable for the reaction with urea. Therefore, future urea sorbents should contain such functional groups at the highest possible density.

\section{INTRODUCTION}

In the human body, urea is a metabolite of nitrogen-containing nutrients such as amino acids. These nutrients are metabolized in the liver into the toxic base ammonia, which is rapidly converted into urea by enzymatic processes. Urea is then transported through the bloodstream to the kidneys, where it is excreted into the urine. ${ }^{1}$ The production of urea in the human body is $230-400 \mathrm{mmol} /$ day. ${ }^{1,2}$ The majority of patients suffering from end-stage kidney disease undergo single pass hemodialysis in a center of three to four times per week to remove urea and other soluble waste products such as potassium, phosphate, and organic compounds from their body. However, the frequent and long visits to a dialysis center compromise their participation in economic and social life. Home hemodialysis therefore offers more flexibility and autonomy for dialysis patients. However, a large complex dialysis machine is required at home in combination with a large supply of dialysis fluids ( $\geq 30 \mathrm{~L} /$ treatment) or a bulky immobile water purification system, which discourages many patients from selecting home hemodialysis. A miniature dialysis device based on continuous regeneration and reuse of dialysate in a closed loop system, free from a fixed water supply, that can easily be used at home and during travel would greatly enhance patient's freedom and autonomy. ${ }^{3,4}$ It would also facilitate more frequent and longer hemodialysis enhancing blood purification, which is expected to improve clinical outcomes and quality of life. ${ }^{5}$
In current miniaturize dialysis devices that are under development, ion exchangers are used to remove excess ions such as phosphate and potassium, while most organic waste solutes such as creatinine and uric acid can effectively be removed by activated carbon. ${ }^{6}$ However, efficient urea removal is still a major obstacle in the development of a lightweight dialysis device. ${ }^{7}$ In principle, three strategies to remove urea from blood dialysate are available: enzymatic conversion, electrochemical degradation, and adsorption by a sorbent. ${ }^{8}$ Enzymatic conversion by immobilized urease, which has been used in the first commercial portable dialysis device that was marketed from 1973 to 1993 (REDY), results in formation of ammonium $\left(\mathrm{NH}_{4}^{+}\right)$and carbon dioxide $\left(\mathrm{CO}_{2}\right){ }^{9}$ The ammonium is removed by a large quantity of a zirconium phosphate ion exchanger, which also captures calcium and magnesium ions that need to be replenished from a reservoir, which limits miniaturization of the device. ${ }^{3,10}$ Electrochemical degradation of urea into nitrogen $\left(\mathrm{N}_{2}\right)$, hydrogen $\left(\mathrm{H}_{2}\right)$, and carbon dioxide $\left(\mathrm{CO}_{2}\right)$ does allow miniaturization of hemodialysis. However, this urea removal method also produces harmful side products such as active chlorine species and reaction products thereof such as chloroamines. ${ }^{8}$ Therefore, ideally, a sorbent is applied that efficiently removes urea from dialysate by physi- or chemisorption. These sorbent

Received: April 24, 2019

Accepted: June 21, 2019

Published: July 10, 2019 
materials are required to be stable that should not leach harmful compounds into the dialysate and should adsorb high quantities of urea from aqueous solution at a sufficient rate. Physisorption in general is a very fast, reversible, and concentration-dependent process. However, all urea sorbents based on physisorption known so far, such as activated carbon and zeolites, have relatively low affinity for urea, and desorption will occur as the urea concentration in the dialysate decreases in time. ${ }^{11,12}$ On the other hand, several polymeric chemisorbents that can bind urea covalently through carbonyl groups have been reported. ${ }^{13-18}$ Despite the weak nucleophilicity of urea nitrogen, it still can react with electrophilic carbonyl groups present in these sorbents such as glyoxaldehydes, ${ }^{13,15}$ ninhydrin groups, ${ }^{14} \alpha$-keto-esters, ${ }^{16}$ and oxidized alcohols. ${ }^{17,18}$ Covalent urea sorbents with binding capacities up to $2.0 \mathrm{mmol} / \mathrm{g}$ have been reported. However, these materials suffer from slow urea binding kinetics at $37^{\circ} \mathrm{C}$ because only a part $(1.2 \mathrm{mmol} / \mathrm{g}$ at most $)$ of the urea-reactive groups has reacted after $8 \mathrm{~h}$, still requiring more than $330 \mathrm{~g}$ of this material to remove the daily urea production (400 mmol). ${ }^{19}$

In the search for a more efficient polymeric urea sorbent suitable for incorporation in a miniature dialysis device, with high binding capacity and fast reaction kinetics, we performed a kinetic study on the covalent binding of urea with a library of low-molecular-weight carbonyl compounds. In the literature, uncatalyzed covalent binding of urea (derivatives) in water has been reported with compounds such as ninhydrin, ${ }^{20-22}$ aromatic glyoxaldehydes, ${ }^{23}$ and other aldehydes. ${ }^{24}$ Based on these reports, we systematically analyzed the kinetics of the reaction of several aromatic carbonyl compounds and nonaromatic analogues thereof with urea in aqueous solution representative for dialysate and determined the second-order rate constant. It is expected that the kinetics of the reaction of carbonyl compounds with urea decreases upon incorporation of the carbonyl groups in a polymeric sorbent due to substituent effects ${ }^{22}$ and decreased accessibility of polymeric groups as compared with molecules in solution. Still, this fundamental knowledge can be used for the future design of urea sorbents with fast kinetics and high binding capacities.

\section{RESULTS AND DISCUSSION}

A carbonyl compound can react with urea in a 1:1 molar ratio. Therefore, first-order dependence in both urea and the carbonyl compound is expected according to eq 1. Indeed, in our previous work, we analyzed the kinetics of urea with ninhydrin substituted with electron-donating groups (EDGs) and electron-withdrawing groups (EWGs) and concluded that the reaction of these ninhydrin derivatives with urea is first order in both urea and ninhydrin and thus second order overall. $^{22}$ Also, the reaction of phenylglyoxaldehyde (PGA) with nucleophilic groups in enzymes such as $\mathrm{NH}_{2}$ groups of arginine residues has been shown to be first order in PGA. ${ }^{25,26}$

$$
\left.\frac{\mathrm{d}[\text { urea }]}{\mathrm{d} t}=-k_{2}[\text { urea }] \text { [carbonyl compound }\right]
$$

Quantitative ${ }^{13} \mathrm{C}$ NMR was previously used as a robust method to determine the $k_{2}$ value of the reaction of urea with ninhydrin (Scheme 1). ${ }^{22}$ Using this method, ${ }^{13} \mathrm{C}$-enriched urea and ninhydrin are reacted in stoichiometric amounts, and therefore, their relative concentrations remain equal throughout the reaction (eq 2). Simplification of eq 1 using eq 2 results in eq 3
Scheme 1. Reaction of Ninhydrin, a Vicinal Tricarbonyl Hydrate, with Urea ${ }^{21}$

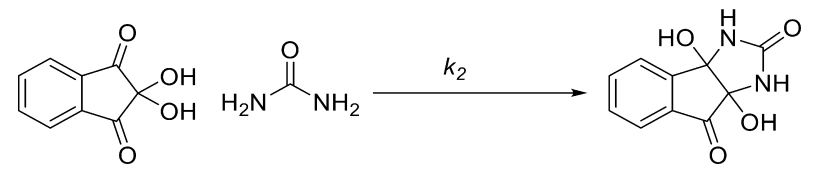

in which the second-order $k_{2}$ value is determined by only measuring urea concentrations in time.

$$
\begin{aligned}
& \text { [urea] }=[\text { carbonyl compound }] \\
& \frac{\mathrm{d}[\text { urea }]}{\mathrm{d} t}=-k_{2}[\text { urea }]^{2}
\end{aligned}
$$

The influence of temperature on the rate of the reaction of ninhydrin with urea was determined in phosphate-buffered aqueous saline (PBS) at temperatures between $20{ }^{\circ} \mathrm{C}(293 \mathrm{~K})$ and $70{ }^{\circ} \mathrm{C}(343 \mathrm{~K})$. The second-order $k_{2}$ values were determined from the plot of the inverse urea concentration in time (Section 2.1 of the Supporting Information), and the $\ln \left(k_{2}\right)$ values were plotted against the inverse of the absolute temperature in the Arrhenius plot (Figure 1). Linear regression

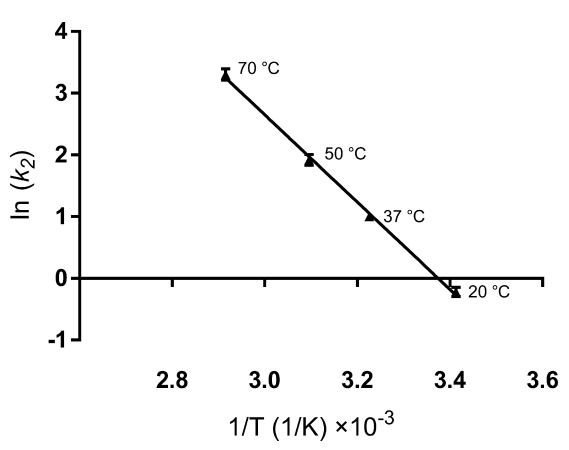

Figure 1. Arrhenius plot of the reaction of ninhydrin with urea in PBS. Linear regression gives $\ln \left(k_{2}\right)=-7073(1 / K)+23.87$. Arrhenius equation: $\ln \left(k_{2}\right)=\left(-E_{\mathrm{a}} / R T\right)+\ln (A)$; thus, $-E_{\mathrm{a}} / R=$ $-7073 \mathrm{~K}$ and $\ln (A)=23.87$.

and the use of Arrhenius equation resulted in a preexponential constant $(A)$ of $(23.3 \pm 0.6) \times 10^{9}$ and an activation energy $\left(E_{\mathrm{a}}\right)$ of $14.0 \pm 0.4 \mathrm{kcal} / \mathrm{mol}$. To have reasonably fast kinetics, the reaction of the carbonyl compounds with urea was carried out at $323 \mathrm{~K}$ unless stated otherwise.

First, hydrates of a variety of similar vicinal tri- and tetraketones were reacted with urea in PBS at $323 \mathrm{~K}$. The structures of the tested carbonyl compounds and the corresponding $k_{2}$ values are listed in Table 1. 2,2-Dihydroxy4,4,5,5-tetramethylcyclopentane-1,3-dione (entry 2) is an aliphatic analogue of ninhydrin and was tested to investigate the influence of the aromatic ring on the reactivity of the vicinal triketone with urea. 2,2,3,3-Tetrahydroxy-2,3-dihydronaphthalene-1,4-dione (entry 3 ) is an analogue of ninhydrin that consists of four vicinal ketones of which two form hydrates. To increase the number of urea-reactive groups per gram of material, also, 2,2,6,6-tetrahydroxy-s-indacene-1,3,5,7$(2 \mathrm{H}, 6 \mathrm{H})$-tetraone (entry 4$)$, which contains two triketone groups, was tested, together with its nonaromatic analogue 2,2,5,5-tetrahydroxy-3a,6a-dimethyl-6-methylenetetrahydropentalene-1,3,4(2H)-trione (entry 5).

Only the aromatic derivatives of the tested vicinal ketone hydrates in Table 1 (entry 1,3 , and 4 ) reacted with urea. The 
Table 1. Structural Formulas of Tested Vicinal Ketone Hydrates and the Determined $k_{2}$ Values of Their Reaction with Urea in PBS at $323 \mathrm{~K}$

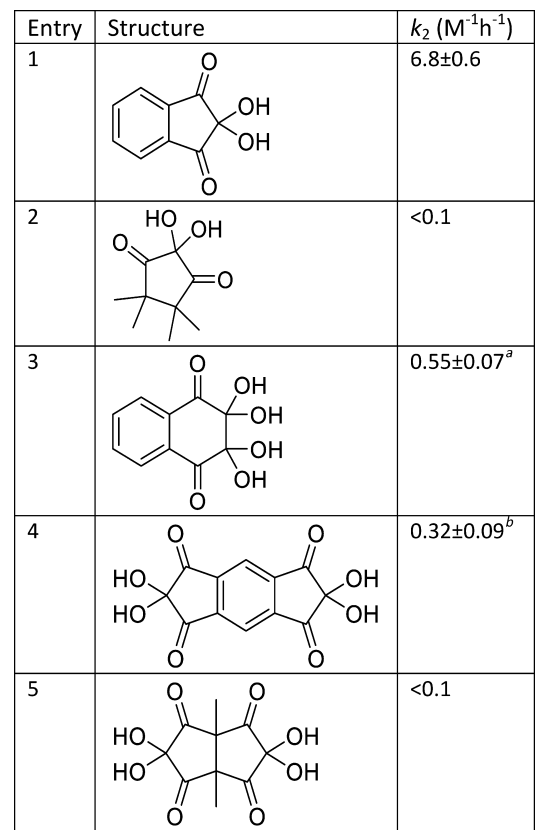

${ }^{a}$ The compound is probably converted into ninhydrin during the reaction with urea. ${ }^{27}{ }^{b}$ Tested in 1:1 (v/v) DMSO/PBS at $343 \mathrm{~K}$ due to its low aqueous solubility.

urea concentration in the reaction mixture containing oxolin (entry 3) did decrease in time; however, the shift of the urea carbon peak in the ${ }^{13} \mathrm{C}$ NMR of the product corresponds to the shift of the same carbon in the ninhydrin-urea adduct (Section 1.1 of the Supporting Information). This suggests that the decrease in the urea concentration is not because of the reaction of oxolin with urea but rather due to the conversion of oxolin into ninhydrin ${ }^{27}$ that subsequently reacts with urea forming the ninhydrin-urea product. In this case, eqs $1-3$ are invalid, and the rate observed cannot be used to calculate the $k$ value of oxolin with urea. Interestingly, the $k_{2}$ value of the reaction of entry 4 with urea substantially decreased by a factor of $\sim 20$ when compared to ninhydrin (entry 1), presumably due to the presence of two EWGs on the opposite site of the aromatic ring, that decreases the rate of dehydration of the hydrate, which is a required step to allow subsequent reaction with urea. ${ }^{22}$

Because phenylglyoxaldehyde (PGA) has been reported to react with urea derivatives, ${ }^{23}$ this compound (Table 2, entry 6) and an aliphatic analogue (entry 7) were tested for the reaction with urea. To increase the amount of urea-reactive groups per gram of material, also, 2,2'-(1,3-phenylene)bis(2-oxoacetaldehyde), a compound with an aromatic ring with two glyoxaldehyde functionalities, was tested (entry 8). For the reaction of phenylglyoxaldehyde with urea, the inverse of the urea concentration in time showed a nonlinear correlation (Section 2.2 and Figure S5, Supporting Information). Identification of the isolated reaction product after $24 \mathrm{~h}$ at $323 \mathrm{~K}$ in PBS by ${ }^{1} \mathrm{H}$ and ${ }^{13} \mathrm{C}$ NMR spectroscopies showed that the initially formed urea-PGA product reacted with another equivalent of PGA. This means that the urea concentration did not remain equal to the PGA concentration during the reaction, and eqs 2 and 3 are therefore invalid, explaining the
Table 2. Structural Formulas of Tested Glyoxaldehydes and the Corresponding $k_{2}$ of Their Reaction with Urea in PBS at $323 \mathrm{~K}$

\begin{tabular}{|l|l|l|}
\hline Entry & Structure & $k_{2}\left(\mathrm{M}^{-1} \mathrm{~h}^{-1}\right)$ \\
\hline 6 & & \\
\hline 8 & & \\
\hline
\end{tabular}

nonlinear correlation observed in the plot of the inverse urea concentration in time. Scheme 2 shows (A) the reaction of

Scheme 2. Reaction and Proposed Mechanism ${ }^{a}$

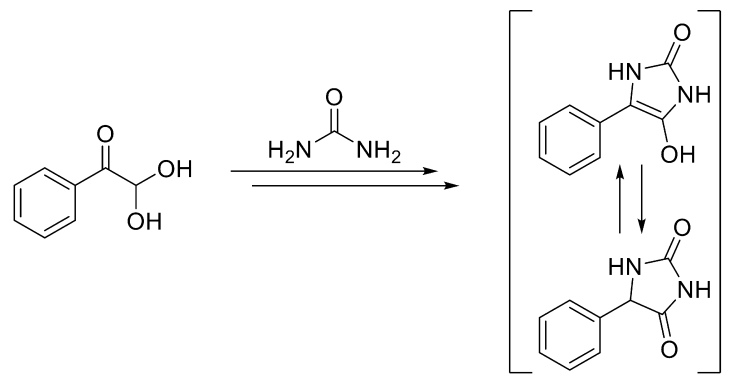

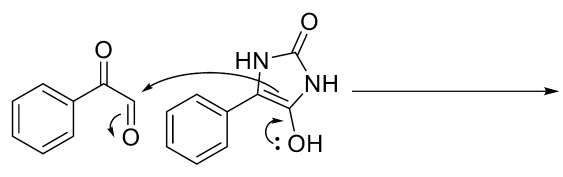<smiles>O=C1NC(=O)C(c2ccccc2)(C(O)C(=O)c2ccccc2)N1</smiles>

a (A) Reaction of hydrated PGA with urea and (B) proposed mechanism of the reaction of the 1:1 PGA-urea adduct with a second PGA molecule; conditions: $0.5 \mathrm{mmol}$ of urea and $0.5 \mathrm{mmol}$ of PGA in $16.7 \mathrm{~mL}$ of PBS ( $30 \mathrm{mM}$ urea and PGA) at $50{ }^{\circ} \mathrm{C}$.

PGA with urea and (B) the proposed mechanism for the formation of the isolated product. Since the final product was isolated in a 57\% yield with respect to PGA and is therefore the major formed product, the reaction of the 1:1 adduct with a second molecule of PGA must be faster than the initial reaction of urea with PGA.

The $k_{2}$ values of the reaction of glyoxaldehydes (Table 2, entries 6-8) with urea were determined from the initial slope of the plot of the inverse urea concentration in time using second-order polynomial regression (Figure S5, Supporting Information). The $k_{2}$ values for the different glyoxaldehydes tested are listed in Table 2. To validate whether the slopes of the lines of Figure S5 can indeed be used for the calculation of the second-order reaction rate constants, PGA was reacted with an excess (3-50 equiv) urea to decrease the probability of the reaction of the 1:1 adduct with another PGA molecule. Thus, pseudo-first-order (PFO) conditions were obtained, and the rate constants $\left(k_{\mathrm{PFO}}\right)$ were measured. In a control 
experiment, ninhydrin $(30 \mathrm{mM})$ was reacted with 5 equiv of urea $(150 \mathrm{mM})$ in $\mathrm{PBS}$, and the $k_{\mathrm{PFO}}$ value was determined to be $1.0 \pm 0.1 \mathrm{~h}^{-1}$ (Section 2.3 of the Supporting Information), which corresponds to a $k_{2}$ of $6.7 \mathrm{M}^{-1} \mathrm{~h}^{-1}\left(1.0 \mathrm{~h}^{-1} / 0.15 \mathrm{M}=\right.$ $6.7 \mathrm{M}^{-1} \mathrm{~h}^{-1}$ ), which is similar to the $k_{2}$ for ninhydrin (Table 1 , entry 1 ). This validates that the $k_{\mathrm{PFO}}$ can indeed be used to determine the $k_{2}$ for the reaction of the carbonyl compound with urea.

The $k_{\mathrm{PFO}}$ values for the reaction of PGA with excess urea were plotted against the [urea] (Section 2.4 and Figure S8, Supporting Information), and this figure shows that $k_{2}$ (as defined of the derivative of $\mathrm{d} k_{\mathrm{PFO}} / \mathrm{d}[\mathrm{urea}]$ ) is not proportional with [urea] but decreases with increasing urea concentration. This is likely because of the dielectric constant of the medium changes, which influences the reactivity of PGA greatly. ${ }^{25,26,28}$ Determination of $k_{2}$ for PGA by extrapolating $k_{\mathrm{PFO}}$ to $30 \mathrm{mM}$ using polynomial regression resulted in a $k_{2}$ of $3.7 \mathrm{M}^{-1} \mathrm{~h}^{-1}$ (Figure S8 and Table S3, Supporting Information), which is similar to $k_{2}$ determined by the initial slope of the plot of the inverse urea concentration in time (Table 2, entry 6), thus validating that this method is an accurate method to determine the $k_{2}$ of glyoxaldehydes.

As for the vicinal ketone hydrates, the aromatic glyoxaldehyde (entry 6) showed a faster reaction with urea than the aliphatic (entry 7) and doubly substituted analogues (entry 8), the latter presumably also due to the decreased rate of dehydration of the hydrate in the presence of the metapositioned EWG.

The enol form of triformylmethane (TFM) (entry 9 of Table 3) is a very electrophilic aldehyde, which has been reported to react with urea to yield an enamine (Scheme 3). ${ }^{24}$ To further investigate the reaction of urea with other aldehydes than TFM, one monoaldehyde and several dialdehydes were selected, and their reaction kinetics with urea was tested (entries 10-13). In addition, electron-poor perfluorated ketones and aldehydes were also tested (entries 14 and 15), as well as a strained four-membered ring diketone (entry 16) and a dialdehyde that potentially forms an aromatic system upon reaction with urea (entry 17 and Section 3 of the Supporting Information). The structures of the selected aldehydes and ketones and the corresponding $k_{2}$ values are listed in Table 3.

In the reaction mixture of urea with TFM (entry 9), the urea concentration dropped very rapidly and remained constant after the first measurement at $30 \mathrm{~min}$ and $323 \mathrm{~K}$. Therefore, besides reacting with urea, we assume that TFM was completely consumed by reacting with itself within this timeframe (as reported by others; see Section 4 of the Supporting Information). ${ }^{29}$ To determine the $k_{2}$ value with sufficient accuracy, the reaction temperature was lowered to room temperature $(293 \mathrm{~K})$, and the initial slope of the plot of the inverse TFM concentration versus time (Figure S9, Supporting Information) showed a $k_{2}$ value of $18.4 \mathrm{M}^{-1} \mathrm{~h}^{-1}$, which is 23 times faster than the reaction of urea with ninhydrin at the same temperature (Figure 1 and Table S2, Supporting Information) making TFM a very interesting compound to build in a urea sorbent.

In contrast to entry 9, the monoaldehyde (entry 10) and the 1,1-, 1,2-, and 1,3-dialdehydes (Table 3, entries 11-13) did not react with urea within $24 \mathrm{~h}$ at $323 \mathrm{~K}$ and $\mathrm{pH}$ 7.4. To allow the initially formed hemiaminal to dehydrate and form a more stable imine, the $\mathrm{pH}$ was decreased to $\mathrm{pH} 2$ (at this $\mathrm{pH}$, urea is not protonated, $\mathrm{p} K_{\mathrm{a}}$ of 0.1$) .{ }^{30}$ Under these conditions, the
Table 3. Structural Formulas of Tested Aldehydes and Ketones and the Determined $k_{2}$ Values of Their Reaction with Urea in PBS at $323 \mathrm{~K}$

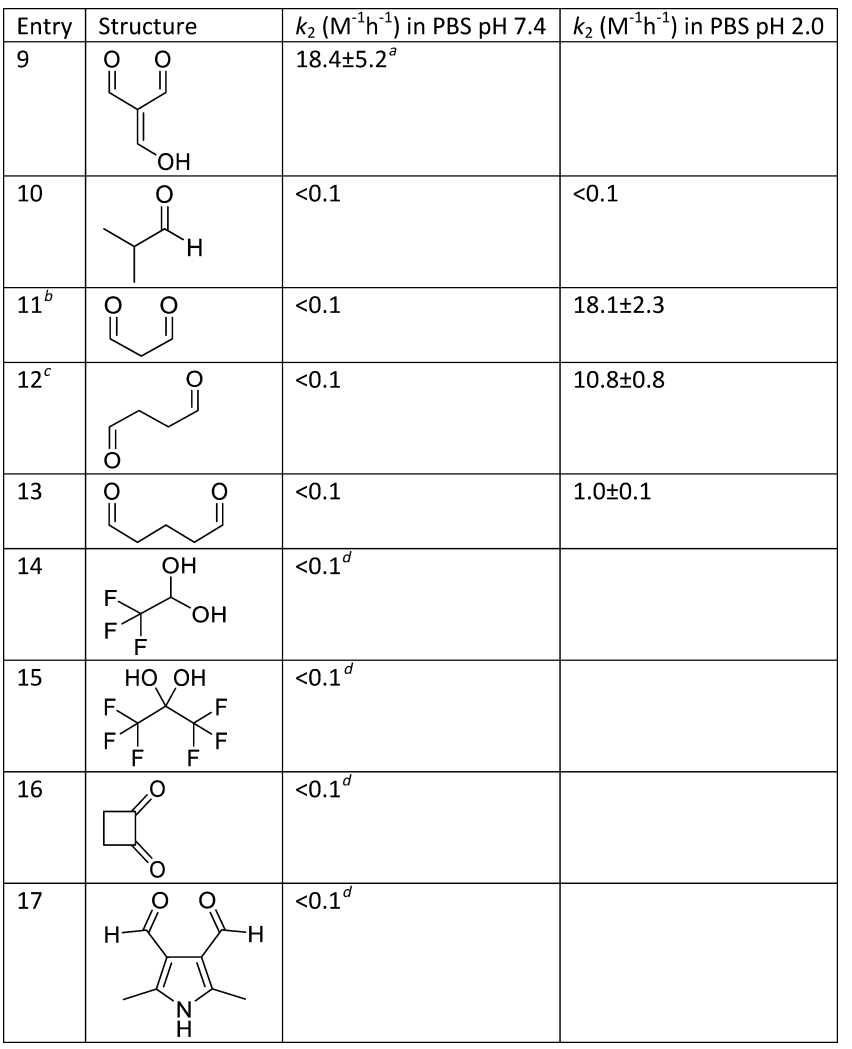

${ }^{a}$ Measured at $293 \mathrm{~K}$ instead of $323 \mathrm{~K}$ to decrease the reaction rate. ${ }^{b} 1,1,3,3$-Tetramethoxypropane was stirred in PBS at pH 2 for 30 min at $\mathrm{RT}$ after which the $\mathrm{pH}$ was adjusted (to $\mathrm{pH} 2$ or 7.4 ), and urea was added to the reaction mixture. ${ }^{c} 2,5$-Dimethoxytetrahydrofuran was stirred in $\mathrm{PBS}$ at $\mathrm{pH} 2$ for $30 \mathrm{~min}$ at $\mathrm{RT}$ after which the $\mathrm{pH}$ was adjusted (to $\mathrm{pH} 2$ or 7.4), and urea was added to the reaction mixture. ${ }^{d}$ Measured both in PBS and 1:1 PBS/DMSO as solvent at $323 \mathrm{~K}$.

Scheme 3. Reaction of Triformylmethane with Urea ${ }^{24}$<smiles>O=CC(C=O)=CO</smiles><smiles>NC(N)=O</smiles><smiles>NC(=O)NC=C(C=O)C=O</smiles>

monoaldehyde still did not react with urea, whereas the dialdehydes did react with urea (Table 3, entry 11-13). The formed hemiaminal will be in equilibrium with the (hydrated) aldehyde. However, the presence of a second aldehyde group makes a second intramolecular nucleophilic attack of urea possible, thus driving the equilibria toward the urea-bound aromatic product (Scheme 4). The results presented in Table 3 show that the kinetics of the reaction with urea decreased with increasing number of carbon atoms between the two aldehyde groups, presumably due to the decreasing mutual inductive electron-withdrawing effect of the aldehydes. Also, intramolecular ring closure likely becomes less favorable when the distance between the urea nitrogen and the aldehyde increases.

Based on these results, we conclude that to drive the equilibrium with water toward the urea adduct, at least two carbonyl groups in close proximity are required, allowing urea to react with both its nitrogens, forming a five- or six- 
Scheme 4. Proposed Mechanisms ${ }^{a}$

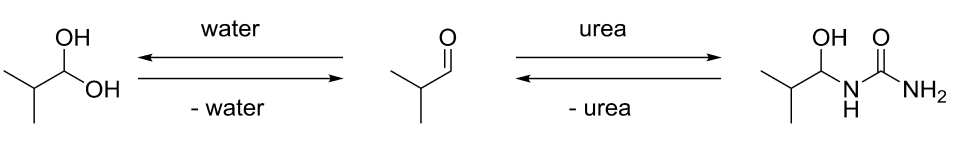

Not observed
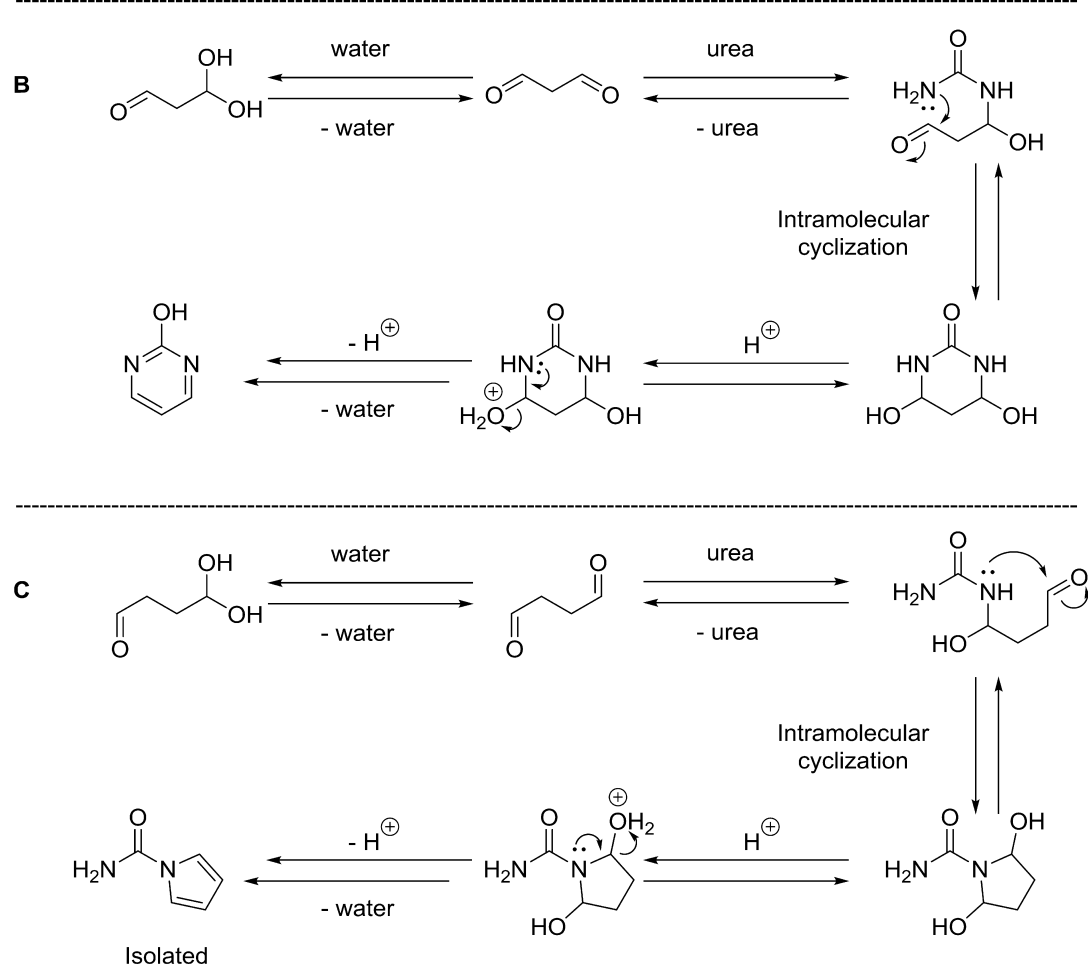

${ }^{a}$ (A) Proposed mechanism of the equilibrium between a monoaldehyde and urea in $\mathrm{H}_{2} \mathrm{O}$; (B, C) proposed mechanism of the acid-catalyzed terminating reaction (B) between a 1,3-dialdehyde and urea in $\mathrm{H}_{2} \mathrm{O}^{31}$ and $(\mathrm{C})$ between a 1,4-dialdehyde and urea in $\mathrm{H}_{2} \mathrm{O}$.

Scheme 5. Dehydration of Ninhydrin and Subsequent Reaction with Urea

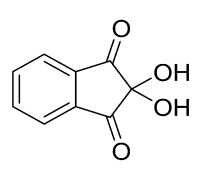

Hydrated Compound

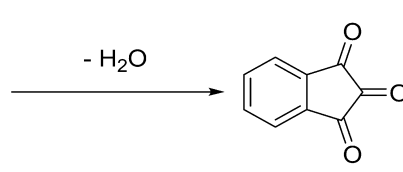

Dehydrated Compound

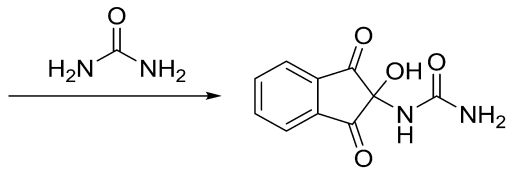

Intermediate Compound membered ring. TFM did not undergo an intramolecular ring closure toward a cyclic product at $\mathrm{pH} 7.4$ because it can easily form a stable enamine at this $\mathrm{pH}$ (Scheme 3). Maltsev et al. have shown that under acidic conditions, TFM, like the dialdehydes tested (entries 11-13), undergoes an intramolecular ring closure into a six-membered ring. ${ }^{32}$

The electron-deficient fluorinated aldehyde and ketone hydrates (entries 14 and 15) did not react with urea under the applied experimental conditions. Also, cyclobutanedione (entry 16) did not react with urea, despite that the reaction with urea could cause release of the ring strain because the hybridization of the carbonyl carbon would change from $\mathrm{sp}^{2}$ to $\mathrm{sp}^{3}$ upon reaction with urea (Table 3 , entry 16 ). The one with the possibility to form an aromatic system upon reaction with urea (Table 3, entry 17) as the possible driving forces did not react with urea, like many other carbonyl compounds that were expected to react with urea but did, in fact, not (listed in Section 1 of the Supporting Information).
To understand why certain carbonyl compounds and hydrates such as ninhydrin and PGA react with urea, whereas carbonyl compounds and hydrates such as hexafluoroacetone (entry 15) and 2,2-dihydroxy-4,4,5,5-tetramethylcyclopentane1,3-dione (entry 2) do not, we calculated the changes in Gibbs free energy $(\Delta G)$ for these reactions using a computational model that we used in our previous study on the reaction of ninhydrin derivatives with urea. ${ }^{22}$ Most of the carbonyl compounds that we tested are predominately present in their hydrated forms. Consequently, the first step in the reaction mechanism is the dehydration of the hydrate and thus the formation of the carbonyl (as shown in Scheme 5 for ninhydrin). ${ }^{22,33}$ The $\Delta G$ of the dehydration of the carbonyl compound was calculated $\left(\Delta G_{\text {dehydration }}\right)$ as well as the subsequent reaction of the dehydrated carbonyl compound with urea to form the intermediate adduct $\left(\Delta G_{\text {intermediate }}\right)$. The structural formulas of the calculated hydrated, dehydrated, and intermediate compounds are listed in Section 5.2 of the Supporting Information. 
Table 4. Structural Formulas, Rate Constants (323 K in PBS, pH 7.4), $\Delta G_{\text {dehydration }}$ and $\Delta G_{\text {intermediate }}$ of Selected Aldehydes and Ketones

\begin{tabular}{|c|c|c|c|c|}
\hline Entry & Hydrated Compound & $k_{2}$-value $\left(\mathrm{M}^{-1} \mathrm{~h}^{-1}\right)$ & $\Delta \mathrm{G}_{\text {dehydration }}(\mathrm{kcal} / \mathrm{mol})$ & $\Delta \mathrm{G}_{\text {intermediate }}(\mathrm{kcal} / \mathrm{mol})$ \\
\hline A & $\mathrm{O} \quad \mathrm{OH}$ & $18.4 \pm 5.2^{a}$ & -10.7 & 14.1 \\
\hline $\mathrm{B}^{b}$ & & $6.8 \pm 0.6$ & -0.8 & 5.4 \\
\hline C & & $3.7 \pm 0.1$ & -6.1 & 7.6 \\
\hline D & & $1.2 \pm 0.0$ & -5.7 & 8.8 \\
\hline E & & $0.78 \pm 0.07$ & -3.5 & 9.2 \\
\hline $\mathrm{F}$ & & $0.32 \pm 0.09^{c}$ & 0.4 & 4.3 \\
\hline G & & $<0.1$ & 1.4 & 3.9 \\
\hline $\mathrm{H}$ & & $<0.1$ & 0.0 & 4.3 \\
\hline 1 & & $<0.1^{d}$ & 2.3 & 8.3 \\
\hline $\mathrm{J}$ & & $<0.1$ & 1.3 & 2.9 \\
\hline $\mathrm{K}$ & & $<0.1$ & 5.1 & 2.5 \\
\hline
\end{tabular}

${ }^{a}$ Measured at $293 \mathrm{~K}$ in PBS pH 7.4. ${ }^{b}$ Data also reported in our earlier work. ${ }^{22}{ }^{c}$ Measured at $343 \mathrm{~K} \mathrm{PBS} / \mathrm{DMSO} 1: 1$ (v/v). ${ }^{d}$ Oxolin is converted into ninhydrin.

By using a continuum solvent model as an approximation in the calculations, the solvation effects might not be accurately represented because the model does not include interactions such as hydrogen bonding. Additionally, the contribution of translational entropy to the Gibbs free energy in the gas phase may be inaccurately treated in solution. For these reasons, the obtained $\Delta G$ values should not be considered absolute values, but they can be compared relatively to each other as all reactions are dehydration or condensation. In fact, actual $\Delta G_{\text {dehydration }}$ should be positive in most cases because the compounds listed in Table 4 are present as the hydrate in water (with exception of TFM, entry A), and the free energy of the hydrate should be lower than the free energy of the corresponding carbonyl compound. NMR analysis showed that TFM is indeed mainly present in its nonhydrated form, which corresponds to the lowest calculated $\Delta G_{\text {dehydration }}$ for this compound. Interestingly, the compounds that react with urea at $323 \mathrm{~K}$ (entries $\mathrm{A}-\mathrm{E}$ ) show a low $\Delta G$ value for dehydration $(-10.7$ to $-3.5 \mathrm{kcal} / \mathrm{mol})$, whereas the hydrates that show a relatively high value for dehydration $(0.0$ to $5.1 \mathrm{kcal} / \mathrm{mol})$ react slowly (entry F) or not (entries $\mathrm{G}-\mathrm{K}$ ) with urea at $343 \mathrm{~K}$. This shows that the Gibbs free energy for dehydration of carbonyl compounds gives a good indication for the reaction rate of the carbonyl compound with urea and can be used to screen promising carbonyl compounds.

TFM shows a rapid reaction with urea (Table 4, entry A) despite the high $\Delta G_{\text {intermediate }}$ because it is primarily dehydrated in solution. Ninhydrin (entry B) has a less favorable dehydration but a relatively low $\Delta G_{\text {intermediate }}$ and shows relatively fast kinetics for the reaction with urea as compared to the other hydrated carbonyl compounds. A clear trend that lower values of $\Delta G_{\text {dehydration }}$ and $\Delta G_{\text {intermediate }}$ coincide with a fast reaction rate with urea is observed for entries $\mathrm{C}-\mathrm{E}$. Carbonyl compounds $\mathrm{F}-\mathrm{K}$ all have a relatively high 
$\Delta G_{\text {dehydration; therefore, the concentration of the urea-reactive }}$ species will be low, resulting in a rate constant of $<0.1 \mathrm{M}^{-1} \mathrm{~h}^{-1}$.

\section{CONCLUSIONS}

In our aim to design an efficient polymeric urea sorbent, the kinetics of the reaction of urea with carbonyl compounds was systematically analyzed. TFM, ninhydrin, and PGA showed the fastest kinetics of their respective class of compounds among the ones tested. Importantly, to react with urea, at least two carbonyl groups are needed in close proximity to allow both nitrogens of urea to react, resulting in the formation of a stable five- or six-membered ring and effectively driving the equilibrium with water toward the urea adduct. This trend is shown for vicinal triketones, glyoxaldehydes, and dialdehydes. TFM, a trialdehdye that is predominately present in its dehydrated form, showed the highest reaction rate with urea and did not form a cyclic product but a stable enamine instead. Computational studies suggest that for carbonyl compounds with a relatively high $\Delta G_{\text {dehydration }}$ the dehydration of the hydrate is unfavorable and therefore the concentration of the urea-reactive species is low resulting in a very slow, often not measurable, reaction with urea.

To design urea sorbents with fast reaction kinetics at physiological conditions, suitable for incorporation in a miniature dialysis device, the focus should be on introducing a high density of functional groups such as TFM, ninhydrin, or PGA, for example, a polymer matrix.

\section{MATERIAL AND METHODS}

General Procedure. All chemicals were obtained from Sigma-Aldrich (Zwijndrecht, The Netherlands) and used as received unless stated otherwise. Phosphate-buffered saline (PBS, $\mathrm{pH}=7.4$; ion composition: $\mathrm{Na}^{+}, 163.9 \mathrm{mM} ; \mathrm{Cl}^{-}, 140.3$ $\mathrm{mM} ; \mathrm{HPO}_{4}{ }^{2-}, 8.7 \mathrm{mM} ; \mathrm{H}_{2} \mathrm{PO}_{4}{ }^{-}, 1.8 \mathrm{mM}$ ) was obtained from B. Braun (Melsungen AG, Germany). 1,1,3,3-Tetramethoxypropane and 2,6-dimethylhepta-2,5-dien-4-one (phorone) were obtained from Combi Blocks (CA, USA). 4-Bromo-2hydroxybenzaldehyde and 1,1'-(1,3-phenylene)bis(ethan-1one) were obtained from AK Scientific (CA, USA). 2Phenylmalonaldehyde was obtained from Apollo Scientific (Manchester, U.K.). 2,2,3,3-Tetrahydroxy-2,3-dihydronaphthalene-1,4-dione and $\left[1,1^{\prime}\right.$-biphenyl $]-2,2^{\prime}$-dicarbaldehyde were obtained from Santa Cruz Biotechnology (CA, USA). 1,1Dihydroxy-3,3-dimethylbutan-2-one was obtained from Enamine (NJ, USA). 3-Isothiocyanatoprop-1-ene was obtained from FluoroChem (Hadfield, U.K.). NMR spectra of the different compounds were recorded on an Agilent 400-MR DD2 equipped with a OneNMR probe or a Bruker $600 \mathrm{MHz}$ with a BBI probe at RT. The quantitative $1 \mathrm{D}{ }^{13} \mathrm{C}$ NMR experiments were carried out on the Agilent 400-MR DD2 using the standard s2pul.c pulse system with a spectral width of 24038.5 $\mathrm{Hz}$ and an acquisition time of $1.363 \mathrm{~s}$. Residual solvent signals were used as internal standard $\left({ }^{1} \mathrm{H}: \delta 2.50 \mathrm{ppm},{ }^{13} \mathrm{C}\left({ }^{1} \mathrm{H}\right): \delta\right.$ $39.52 \mathrm{ppm}$ for DMSO- $d_{6}$; ${ }^{1} \mathrm{H}: \delta 7.26 \mathrm{ppm},{ }^{13} \mathrm{C}\left({ }^{1} \mathrm{H}\right): \delta 77.16$ ppm for $\mathrm{CDCl}_{3} ;{ }^{1} \mathrm{H}$ : $\delta 5.32 \mathrm{ppm},{ }^{13} \mathrm{C}\left({ }^{1} \mathrm{H}\right): \delta 53.84 \mathrm{ppm}$ for $\left.\mathrm{CD}_{2} \mathrm{Cl}_{2}\right)$. Chemical shifts $(\delta)$ are given in ppm, and coupling constants $(J)$ are given in hertz $(\mathrm{Hz})$. Resonances are described as s (singlet), d (doublet), $t$ (triplet), q (quartet), bs (broad singlet), and $\mathrm{m}$ (multiplet), or combinations thereof. UV absorption spectra and intensities were recorded with a BMG LABTECH SpectroStar Nano platereader using UV-Star Microplate 96 well obtained from Greiner Bio-One (Alphen aan de Rijn, The Netherlands). Flash chromatography was performed over silica gel (particle size of $40-63 \mu \mathrm{m}$, VWR Chemicals, Leuven, Belgium) using the indicated eluent. Thinlayer chromatography (TLC) was performed using TLC plates from Merck Darmstadt, Germany, $\left(\mathrm{SiO}_{2}\right.$, Kieselgel 60 F254 neutral, on aluminum with a fluorescence indicator), and the compounds were visualized by UV detection $(254 \mathrm{~nm})$.

General Procedure for the Kinetic Analysis of the Carbonyl Compounds with Urea. The carbonyl compound of interest ( $0.5 \mathrm{mmol}, 1.0$ equiv) was dissolved in $16.7 \mathrm{~mL}$ of PBS or a $1: 1(\mathrm{v} / \mathrm{v})$ mixture of DMSO and PBS. ${ }^{13} \mathrm{C}$-labeled urea ( $31.5 \mathrm{mg}, 0.5 \mathrm{mmol}, 1.0$ equiv) was added to the solution, and the mixture was stirred magnetically at the indicated temperature for 2-96 h. Samples from the reaction were taken at different time points, and the urea concentrations in the different samples were determined by quantitative ${ }^{13} \mathrm{C} N M R$ (see below). The kinetic experiment was continued until more than $50 \%$ conversion was reached or when the urea concentration remained constant. The $k_{2}$ values for the carbonyl compounds were determined from the plots of 1 / [urea] versus time.

Determination of Urea Concentration by ${ }^{13} \mathrm{C} \mathrm{NMR}^{22}$ For the calibration curve, a stock solution of ${ }^{13} \mathrm{C}$-labeled urea in PBS (50 mM) was prepared and diluted to $5,10,15,20,25$, 30 , and $35 \mathrm{mM}$. A solution of $\mathrm{Me}_{2} \mathrm{SO}_{2}$ in $\mathrm{D}_{2} \mathrm{O}(1.50 \mathrm{mmol}$ in $1000 \mu \mathrm{L}, 1.34 \mathrm{M})$ was prepared and added to the analytes in a 10:1 ratio $(1000 \mu \mathrm{L}$ of analyte and $100 \mu \mathrm{L}$ of internal standard). The mixture was shaken, and $600 \mu \mathrm{L}$ was transferred into an NMR tube. For reaction mixtures in 1:1 PBS/DMSO, $200 \mu \mathrm{L}$ of internal standard solution was added to $1000 \mu \mathrm{L}$ of reaction mixture and transferred into an NMR tube. During the $1 \mathrm{D}{ }^{13} \mathrm{C}$ NMR experiments $(101 \mathrm{MHz})$, proton signals were decoupled. FIDs were Fourier transformed and automatic phase correction, and the third-order polynomial baseline correction and automatic integration were applied with MestReNova version 10.0.2-15465. Intra- and interassay coefficients of variation were within $10 \%$. The ratios of integrals for urea at $162.08 \mathrm{ppm}$ and internal standard at $42.15 \mathrm{ppm}$ were compared with those of the calibration curve for calculating urea concentration in the samples.

Identification of Urea-Dialdehyde Adduct under Acidic Conditions. 2,5-Dimethoxytetrahydrofuran (mixture of cis and trans) ( $0.5 \mathrm{mmol}, 1.0$ equiv) was dissolved in PBS, and the $\mathrm{pH}$ was adjusted with $1 \mathrm{M} \mathrm{HCl}$ to $\mathrm{pH} 2$ and stirred for $30 \mathrm{~min}$ at RT. Urea ( $300.3 \mathrm{mg}, 5 \mathrm{mmol}, 10$ equiv) was added, and the reaction mixture was heated to $50{ }^{\circ} \mathrm{C}$ and stirred for 5 h. The mixture was allowed to cool to RT and freeze-dried. The crude mixture was purified over silica (EtOAc/MeOH 19:1), and the ${ }^{1} \mathrm{H}$ NMR spectra of the isolated compound corresponded with $1 H$-pyrrole-1-carboxamide. ${ }^{34}$

Determination of Carbonyl Compound Concentration by UV. A carbonyl compound stock solution $(30 \mathrm{mM})$ in PBS was diluted 30 times $(4350 \mu \mathrm{L}$ of PBS $+150 \mu \mathrm{L}$ of 30 $\mathrm{mM}$ stock solution) to a $1 \mathrm{mM}$ stock solution. A calibration curve was prepared by diluting the $1 \mathrm{mM}$ stock solution to $0.005,0.010,0.020,0.040,0.060,0.080,0.100$, and $0.120 \mathrm{mM}$ with PBS. Samples of the solutions $(200 \mu \mathrm{L})$ were transferred into a UV-Star 96-well plate in triplo. The concentration of the carbonyl compound in the reaction mixture was determined by taking a sample and directly diluting it 300 times at RT (30 times dilution; $150 \mu \mathrm{L}$ of reaction mixture $+4350 \mu \mathrm{L}$ of PBS) followed by 10 times dilution ( $150 \mu \mathrm{L}$ of sample $+1350 \mu \mathrm{L}$ of PBS) after which $200 \mu \mathrm{L}$ was transferred into the UV-Star 96- 
well plate in triplo. The TFM, ninhydrin, or PGA concentration in the samples was determined with the average UV absorption of 3 wells at 248, 232, and $250 \mathrm{~nm}$, respectively.

Computational Studies. DFT calculations were performed using the Gaussian 09 software package, using the B3LYP (Becke, three-parameter, Lee-Yang-Parr) functional with 6-31 $\mathrm{g}(\mathrm{d}, \mathrm{p})$ as the basis set on all atoms. ${ }^{35}$ Structure optimizations were carried out with water as a solvent without any symmetry restrains in water. Frequency analyses were performed on all calculations. Input: \#B3LYP/6-31G(d,p) opt $=$ tight freq $s c f=$ tight int. $=$ ultrafine pop $=$ regular $\mathrm{SCRF}=$ (solvent $=$ water $)$.

Syntheses and Spectroscopic Data. Synthesis of 4,4,3,3-Tetramethylcyclopentane-1,2,3-trione Hydrate. ${ }^{36,37}$<smiles>CC(C)(Br)C(Br)C(=O)C(Br)C(C)(C)Br</smiles>

Bromine (10.3 mL, $145 \mathrm{mmol}, 2.0$ equiv) was dissolved in $\mathrm{CH}_{2} \mathrm{Cl}_{2}(50 \mathrm{~mL})$. The solution was cooled to $0{ }^{\circ} \mathrm{C}$, and $2,6-$ dimethylhepta-2,5-dien-4-one (10 g, $72.5 \mathrm{mmol}, 1.0$ equiv) was dissolved $\mathrm{CH}_{2} \mathrm{Cl}_{2}(50 \mathrm{~mL})$ and added dropwise. Next, the reaction mixture was stirred for $1 \mathrm{~h}$ at $0{ }^{\circ} \mathrm{C}$. The solvent was evaporated, and the crude mixture was recrystallized from EtOH, yielding 2,3,5,6-tetrabromo-2,6-dimethylheptan-4-one as a white solid $(27.8 \mathrm{~g}, 60.9 \mathrm{mmol}, 84 \%) .{ }^{1} \mathrm{H} \mathrm{NMR}\left(\mathrm{CDCl}_{3}\right.$, $400 \mathrm{MHz}, \delta)$ main isomer: $5.15(\mathrm{~s}, 2 \mathrm{H}), 2.02(\mathrm{~s}, 12 \mathrm{H}) .{ }^{13} \mathrm{C}$ $\operatorname{NMR}\left(\mathrm{CDCl}_{3}, \delta\right)$ main isomer: $193.88\left(\mathrm{C}_{\mathrm{q}}\right), 62.83\left(\mathrm{C}_{\mathrm{q}}\right), 59.62$ $(\mathrm{CH}), 33.90\left(\mathrm{CH}_{3}\right), 29.29\left(\mathrm{CH}_{3}\right)$.<smiles>CC(C)=C(Br)C(=O)C(Br)=C(C)C</smiles>

2,3,5,6-Tetrabromo-2,6-dimethylheptan-4-one (50 mmol, 1.0 equiv) was dissolved in cold pyridine $(30 \mathrm{~mL})$ and kept for $24 \mathrm{~h}$ at $0{ }^{\circ} \mathrm{C}$ without stirring. The reaction mixture was transferred into a separation funnel with $\mathrm{CH}_{2} \mathrm{Cl}_{2}$, washed with $30 \% \mathrm{H}_{2} \mathrm{SO}_{4}$ (twice), $\mathrm{H}_{2} \mathrm{O}$, and brine, and dried over $\mathrm{Na}_{2} \mathrm{SO}_{4}$. After evaporation of the solvent, 3,5-dibromo-2,6-dimethylhepta-2,5-dien-4-one was isolated as a brown oil, which started crystalizing when dried under vacuum and at RT (5.35 g, 49 mmol, 98\%). ${ }^{1} \mathrm{H}$ NMR $\left(\mathrm{CDCl}_{3}, 400 \mathrm{MHz}, \delta\right): 2.04$ (s, 6H), 1.99 (s, 6H). ${ }^{13} \mathrm{C} \mathrm{NMR}\left(\mathrm{CDCl}_{3}, 101 \mathrm{MHz}, \delta\right): 190.25\left(\mathrm{C}_{\mathrm{q}}\right)$, $144.98\left(\mathrm{C}_{\mathrm{q}}\right), 115.64\left(\mathrm{C}_{\mathrm{q}}\right), 25.99\left(\mathrm{CH}_{3}\right), 22.55\left(\mathrm{CH}_{3}\right)$.<smiles>CC1(C)C(=O)C(O)=C(Br)C1(C)C</smiles>

3,5-Dibromo-2,6-dimethylhepta-2,5-dien-4-one (4.158 g, 16 mmol, 1.0 equiv) was dissolved in cold $\mathrm{H}_{2} \mathrm{SO}_{4}(2.56 \mathrm{~mL}, 48$ mmol, 3.0 equiv) and stirred at $0{ }^{\circ} \mathrm{C}$ for $24 \mathrm{~h}$. The mixture was poured over crushed ice during which 3-bromo-2-hydroxy4,4,5,5-tetramethylcyclopent-2-en-1-one precipitated. The resulting suspension was filtered, and the obtained solid material was washed with water and dried under vacuum at RT, yielding 3-bromo-2-hydroxy-4,4,5,5-tetramethylcyclopent-2-en-1-one in a $76 \%$ yield $(2.8 \mathrm{~g}, 12 \mathrm{mmol}) .{ }^{1} \mathrm{H} \mathrm{NMR}\left(\mathrm{CDCl}_{3}, 400 \mathrm{MHz}, \delta\right)$ : 5.82 (bs, OH), 1.13 (s, 6H), $1.11(\mathrm{~s}, 6 \mathrm{H}) .{ }^{13} \mathrm{C} \mathrm{NMR}\left(\mathrm{CDCl}_{3}\right.$, $101 \mathrm{MHz}, \delta): 204.73\left(\mathrm{C}_{\mathrm{q}}\right), 147.49\left(\mathrm{C}_{\mathrm{q}}\right), 138.72\left(\mathrm{C}_{\mathrm{q}}\right), 51.18$ $\left(\mathrm{C}_{\mathrm{q}}\right), 46.60\left(\mathrm{C}_{\mathrm{q}}\right), 24.99\left(\mathrm{CH}_{3}\right), 22.64\left(\mathrm{CH}_{3}\right)$.

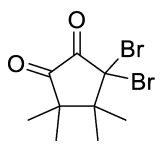

3-Bromo-2-hydroxy-4,4,5,5-tetramethylcyclopent-2-en-1-one ( $3.5 \mathrm{mmol}, 1.0$ equiv) was dissolved in cold acetic acid $(4 \mathrm{~mL})$ to which bromine ( $178 \mu \mathrm{L}, 3.5 \mathrm{mmol}, 1.0$ equiv) in acetic acid $(4 \mathrm{~mL})$ was slowly added at $0{ }^{\circ} \mathrm{C}$. The reaction mixture was allowed to heat to RT and stirred for $2 \mathrm{~h}$. The mixture was poured over ice and rested for $10 \mathrm{~min}$. The suspension was filtrated, and the obtained solid material was washed with water and dried under vacuum, yielding 3,3-dibromo-4,4,5,5tetramethylcyclopentane-1,2-dione as a brown solid in a $38 \%$ yield (419 mg, $1.34 \mathrm{mmol}) .{ }^{1} \mathrm{H}$ NMR $\left(\mathrm{CDCl}_{3}, 400 \mathrm{MHz}, \delta\right)$ : 1.39 (s, 6H), $1.34(\mathrm{~s}, 6 \mathrm{H}) .{ }^{13} \mathrm{C} \mathrm{NMR}\left(\mathrm{CDCl}_{3}, 101 \mathrm{MHz}, \delta\right)$ : $214.13\left(\mathrm{C}_{\mathrm{q}}\right), 204.74\left(\mathrm{C}_{\mathrm{q}}\right), 73.32\left(\mathrm{C}_{\mathrm{q}}\right), 50.68\left(\mathrm{C}_{\mathrm{q}}\right), 46.92\left(\mathrm{C}_{\mathrm{q}}\right)$, $25.45\left(\mathrm{CH}_{3}\right), 24.10\left(\mathrm{CH}_{3}\right)$.<smiles>CC1(C)C(=O)C(O)(O)C(=O)C1(C)C</smiles>

The procedure as described by Gill et al. and Shoppee ${ }^{36,37}$ did not yield 2,2-dihydroxy-4,4,5,5-tetramethylcyclopentane1,3-dione in our hands. Therefore, we modified the procedure inspired by the work of Liang et al. ${ }^{38}$ 3,3-Dibromo-4,4,5,5tetramethylcyclopentane-1,2-dione (157 mg, $0.5 \mathrm{mmol}, 1.0$ equiv) was dissolved in DMSO $(1 \mathrm{~mL})$, and iodine $(0.1 \mathrm{mmol}$, 0.2 equiv) and water ( $0.5 \mathrm{mmol}, 1.0$ equiv) were added. The reaction mixture was stirred at $50{ }^{\circ} \mathrm{C}$ for $24 \mathrm{~h}$ after which the resulting mixture was freeze-dried to remove DMSO. Purification of the crude mixture over silica (hexane/EtOAc 1:1) yielded 2,2-dihydroxy-4,4,5,5-tetramethylcyclopentane1,3-dione as a yellow solid in a $90 \%$ yield. ${ }^{1} \mathrm{H} \mathrm{NMR}\left(\mathrm{CDCl}_{3}\right.$, $400 \mathrm{MHz}, \delta$ ): 6.02 (bs, $2 \mathrm{H}), 1.14(\mathrm{~s}, 6 \mathrm{H}), 1.12$ (s, 6H). These peak shifts differ from those reported by Gill et al. and Shoppee $(\delta: 1.20(\mathrm{~s}, 6 \mathrm{H})$ and $1.08(\mathrm{~s}, 6 \mathrm{H})) \cdot{ }^{13} \mathrm{C}$ NMR $\left(\mathrm{CDCl}_{3}, 101 \mathrm{MHz}, \delta\right): 214.21\left(\mathrm{C}_{\mathrm{q}}\right), 137.78\left(\mathrm{C}_{\mathrm{q}}\right), 51.10\left(\mathrm{C}_{\mathrm{q}}\right)$, $24.97\left(\mathrm{CH}_{3}\right), 22.61\left(\mathrm{CH}_{3}\right)$.

Synthesis of s-Indacene-1,2,3,5,6,7-hexaone Hydrate.<smiles>O=C1c2cc3c(cc2C(=O)C1(O)O)C(=O)C(O)(O)C3=O</smiles>

$s$-Indacene-1,3,5,7 $(2 \mathrm{H}, 6 \mathrm{H})$-tetraone was synthesized according to the procedure of Krief et al. ${ }^{39}\left({ }^{1} \mathrm{H}\right.$ NMR $\left(\mathrm{CD}_{2} \mathrm{Cl}_{2}, 400 \mathrm{MHz}\right.$ $\delta): 8.48(\mathrm{~s}, 2 \mathrm{H}), 3.42(\mathrm{~s}, 4 \mathrm{H}))$ and oxidized into $s$-indacene$1,2,3,5,6,7$-hexaone hydrate according to the procedure reported by Marminon et al. ${ }^{40} s$-Indacene-1,3,5,7 $(2 \mathrm{H}, 6 \mathrm{H})$ tetraone ( $171 \mathrm{mg}, 0.8 \mathrm{mmol}, 1.0$ equiv) was dissolved in a 10:1 mixture of dioxane $(3 \mathrm{~mL})$ and $\mathrm{H}_{2} \mathrm{O}(0.3 \mathrm{~mL})$ in a microwave tube equipped with a magnetic stirrer. Selenium dioxide $(275$ $\mathrm{mg}, 2.5 \mathrm{mmol}, 3.1$ equiv) was added, and the tube was sealed. The mixture was shaken vigorously until selenium dioxide was dissolved, and the tube was placed in the microwave where it was heated for $5 \mathrm{~min}$ at $180^{\circ} \mathrm{C}$. The crude reaction mixture was impregnated on silica and purified over silica (8:1 $\left.\mathrm{CH}_{2} \mathrm{Cl}_{2} / \mathrm{MeOH}\right)$, obtaining the product in a $30 \%$ yield $(66$ $\mathrm{mg}, 0.24 \mathrm{mmol}$ ). ${ }^{1} \mathrm{H}$ NMR (DMSO, $600 \mathrm{MHz}, \delta$ ): 8.45 (s, $2 \mathrm{H}), 7.82(\mathrm{bs}, 4 \mathrm{H}) .{ }^{13} \mathrm{C}$ NMR (DMSO, $\left.125 \mathrm{MHz}, \delta\right): 195.66$ $\left(\mathrm{C}_{\mathrm{q}}\right), 143.66\left(\mathrm{C}_{\mathrm{q}}\right), 119.68(\mathrm{CH}), 88.31\left(\mathrm{C}_{\mathrm{q}}\right)$.

Synthesis of 3a,6a-Dimethyldihydropentalene-1,2,3,4,5,6hexaone.

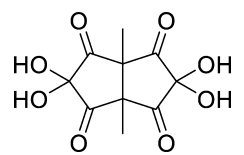


3a,6a-Dimethyltetrahydropentalene-2,5 $(1 H, 3 H)$-dione (499 $\mathrm{mg}, 3.0 \mathrm{mmol}, 1.0$ equiv) was dissolved in DMSO, and $48 \%$ $\mathrm{HBr}$ (4.1 mL, $36 \mathrm{mmol}, 12$ equiv), 57\% HI (171 $\mu \mathrm{L}, 1.5 \mathrm{mmol}$, 0.5 equiv), and $\mathrm{I}_{2}$ (380 mg, $1.5 \mathrm{mmol}, 0.5$ equiv) were added. The mixture was stirred magnetically at $80{ }^{\circ} \mathrm{C}$ for $4 \mathrm{~h}$. Afterward, the mixture was allowed to cool to RT and was extracted with $\mathrm{CH}_{2} \mathrm{Cl}_{2}$ five times. The organic layers were combined, dried over $\mathrm{Na}_{2} \mathrm{SO}_{4}$, and concentrated during which red crystals precipitated from the solution. After filtration, the crystals were collected in a $36 \%$ yield $(279 \mathrm{mg}, 1.1 \mathrm{mmol}) .{ }^{1} \mathrm{H}$ NMR (DMSO, $400 \mathrm{MHz}, \delta$ ): 10.68 (bs, 4H), 1.41 (s, 3H), $1.32(\mathrm{~s}, 3 \mathrm{H}) .{ }^{13} \mathrm{C}$ NMR (DMSO, $\left.101 \mathrm{MHz}, \delta\right): 191.81\left(\mathrm{C}_{\mathrm{q}}\right)$, $148.24\left(\mathrm{C}_{\mathrm{q}}\right), 133.28\left(\mathrm{C}_{\mathrm{q}}\right), 65.11\left(\mathrm{C}_{\mathrm{q}}\right), 52.39\left(\mathrm{C}_{\mathrm{q}}\right), 19.47$ $\left(\mathrm{CH}_{3}\right), 17.08\left(\mathrm{CH}_{3}\right)$.

Synthesis of 5-(1-Hydroxy-2-oxo-2-phenylethyl)-5-phenylimidazolidine-2,4-dione.

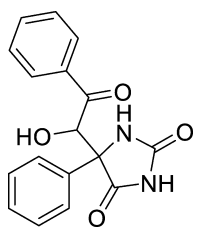

Phenylglyoxaldehyde (456 mg, $3.0 \mathrm{mmol}, 1.0$ equiv) was dissolved under continuous stirring in PBS $(100 \mathrm{~mL})$, and urea (180 mg, $3.0 \mathrm{mmol}, 1.0$ equiv) was added. The reaction mixture was heated to $50{ }^{\circ} \mathrm{C}$ and stirred for $24 \mathrm{~h}$. Afterward, the mixture was allowed to cool to RT, and the solvent was removed by freeze-drying. The crude reaction mixture was impregnated on silica and purified over silica (hexanes/EtOAc = 5:1), obtaining 5-(1-hydroxy-2-oxo-2-phenylethyl)-5-phenylimidazolidine-2,4-dione as a mixture of diastereomers $(266 \mathrm{mg}$, $0.86 \mathrm{mmol}$ ) as a white solid in a $57 \%$ yield with respect to phenylglyoxaldehyde. Major diastereomer: ${ }^{1} \mathrm{H}$ NMR (DMSO, $400 \mathrm{MHz}, \delta$ ): 10.77 (bs, $1 \mathrm{H}), 8.23$ (bs, $1 \mathrm{H}), 7.82$ (d, $J=8.3$ $\mathrm{Hz}, 2 \mathrm{H}), 7.59$ (d, $J=8.2 \mathrm{~Hz}, 2 \mathrm{H}), 7.53(\mathrm{~m}, 1 \mathrm{H}), 7.40(\mathrm{t}, J=$ $7.6 \mathrm{~Hz}, 2 \mathrm{H}), 7.25(\mathrm{t}, J=7.6 \mathrm{~Hz}, 2 \mathrm{H}), 7.18(\mathrm{~m}, 1 \mathrm{H}), 6.65(\mathrm{~d}, J$ $=8.7 \mathrm{~Hz}, 1 \mathrm{H}), 5.71(\mathrm{~d}, J=8.5 \mathrm{~Hz}, 1 \mathrm{H}) .{ }^{13} \mathrm{C}$ NMR (DMSO, $101 \mathrm{MHz}, \delta): 196.77\left(\mathrm{C}_{\mathrm{q}}\right), 174.88\left(\mathrm{C}_{\mathrm{q}}\right), 157.11\left(\mathrm{C}_{\mathrm{q}}\right), 136.02$ $\left(\mathrm{C}_{\mathrm{q}}\right), 135.48\left(\mathrm{C}_{\mathrm{q}}\right), 133.33(\mathrm{CH}), 128.69(\mathrm{CH}), 128.43(\mathrm{CH})$, $128.09(\mathrm{CH}), 127.68(\mathrm{CH}), 125.78(\mathrm{CH}), 73.64(\mathrm{CH}), 70.60$ $\left(\mathrm{C}_{\mathrm{q}}\right)$.

Synthesis of 1,1'-(1,3-Phenylene)bis(2,2-dihydroxyethan1-one).<smiles>O=C(c1cccc(C(=O)C(O)O)c1)C(O)O</smiles>

1,1'-(1,3-Phenylene)bis(ethan-1-one) (162 mg, $1.0 \mathrm{mmol}, 1.0$ equiv) was dissolved in a 10:1 mixture of dioxane $(3 \mathrm{~mL})$ and $\mathrm{H}_{2} \mathrm{O}(0.3 \mathrm{~mL})$ in a microwave tube equipped with a magnetic stirrer. Selenium dioxide ( $344 \mathrm{mg}, 3.1 \mathrm{mmol}, 3.1$ equiv) was added, and the tube was sealed. The mixture was shaken vigorously until selenium dioxide was completely dissolved, and the tube was placed in the microwave oven in which it was heated for $5 \mathrm{~min}$ at $180{ }^{\circ} \mathrm{C}$. The crude reaction mixture was impregnated on silica and purified over silica (EtOAc), obtaining an orange oil in a $41 \%$ yield $(93 \mathrm{mg}, 0.41 \mathrm{mmol}$ ). ${ }^{1} \mathrm{H}$ NMR (DMSO, $\left.600 \mathrm{MHz}, \delta\right): 8.71(\mathrm{t}, J=2.0 \mathrm{~Hz}, 1 \mathrm{H}), 8.32$ $(\mathrm{m}, 2 \mathrm{H}), 7.66(\mathrm{t}, J=7.6 \mathrm{~Hz}, 1 \mathrm{H}), 6.90(\mathrm{bs}, 4 \mathrm{OH}), 5.68(\mathrm{~s}$, $2 \mathrm{H}) .{ }^{13} \mathrm{C}$ NMR (DMSO, $\left.125 \mathrm{MHz}, \delta\right): 188.67\left(\mathrm{C}_{\mathrm{q}}\right), 133.92$ $(\mathrm{CH}), 133.84\left(\mathrm{C}_{\mathrm{q}}\right), 130.07(\mathrm{CH}), 128.64(\mathrm{CH}), 89.64(\mathrm{CH})$.
Synthesis of Triformylmethane.<smiles>O=CC(C=O)=CO</smiles>

Triformylmethane was synthesized according to the procedure of Buděśinský et al. ${ }^{41}{ }^{1} \mathrm{H} \mathrm{NMR}\left(\mathrm{CDCl}_{3}, 400 \mathrm{MHz}, \delta\right): 9.50(\mathrm{~s}$, $1 \mathrm{H}), 9.02(\mathrm{~s}, 2 \mathrm{H}) .{ }^{13} \mathrm{C} \mathrm{NMR}\left(\mathrm{CDCl}_{3}, 101 \mathrm{MHz}, \delta\right): 186.60$ $(\mathrm{CH}), 118.42\left(\mathrm{C}_{\mathrm{q}}\right)$. One ${ }^{13} \mathrm{C}$ signal is not observed, possibly due to tautomerization.

\section{ASSOCIATED CONTENT}

\section{Supporting Information}

The Supporting Information is available free of charge on the ACS Publications website at DOI: 10.1021/acsomega.9b01177.

Structures of carbonyl compounds tested that are not listed in main manuscript; ${ }^{13} \mathrm{C}$ NMR spectra of the reaction products of oxolin and ninhydrin with ${ }^{13} \mathrm{C}$ labeled urea; plots of the inverse urea concentration in time for the reaction of urea with carbonyl compounds; PFO experiments of PGA and ninhydrin with excess urea; scheme of the reaction of entry 17 with urea; overview of side reactions of TFM in water; details of the computational data; structural formulas, calculated $G$ values and optimized coordinates of all hydrated, dehydrated, and intermediate compounds; ${ }^{1} \mathrm{H}$ and ${ }^{13} \mathrm{C}$ NMR spectra of synthesized compounds (PDF)

\section{AUTHOR INFORMATION}

\section{Corresponding Author}

*E-mail: c.f.vannostrum@uu.nl.

ORCID $\odot$

Jacobus A. W. Jong: 0000-0002-4896-4744

Wim E. Hennink: 0000-0002-5750-714X

Cornelus F. Van Nostrum: 0000-0003-4210-5241

Notes

The authors declare no competing financial interest.

\section{ACKNOWLEDGMENTS}

This research was supported by the Dutch organization for Scientific Research (NWO-TTW, project 14433) and the Dutch Kidney Foundation. M.-E.M. acknowledges the Sectorplan Natuur- en Scheikunde (Tenure-track grant at Utrecht University) for financial support.

\section{REFERENCES}

(1) Weiner, I. D.; Mitch, W. E.; Sands, J. M. Urea and Ammonia Metabolism and the Control of Renal Nitrogen Excretion. Clin. J. Am. Soc. Nephrol. 2015, 10, 1444-1458.

(2) Shinaberger, C. S.; Kilpatrick, R. D.; Regidor, D. L.; McAllister, C. J.; Greenland, S.; Kopple, J. D.; Kalantar-Zadeh, K. Longitudinal Associations Between Dietary Protein Intake and Survival in Hemodialysis Patients. Am. J. Kidney Dis. 2006, 48, 37-49.

(3) Davenport, A.; Gura, V.; Ronco, C.; Beizai, M.; Ezon, C.; Rambod, E. A wearable haemodialysis device for patients with endstage renal failure: a pilot study. Lancet 2007, 370, 2005-2010.

(4) Davenport, A. Dialysis: A wearable dialysis device: the first step to continuous therapy. Nat. Rev. Nephrol. 2016, 12, 512-4.

(5) Rocco, M. V.; Lockridge, R. S., Jr.; Beck, G. J.; Eggers, P. W.; Gassman, J. J.; Greene, T.; Larive, B.; Chan, C. T.; Chertow, G. M.; Copland, M.; Hoy, C. D.; Lindsay, R. M.; Levin, N. W.; Ornt, D. B.; Pierratos, A.; Pipkin, M. F.; Rajagopalan, S.; Stokes, J. B.; Unruh, M. 
L.; Star, R. A.; Kliger, A. S. The effects of frequent nocturnal home hemodialysis: the Frequent Hemodialysis Network Nocturnal Trial. Kidney Int. 2011, 80, 1080-1091.

(6) Agar, J. W. Review: understanding sorbent dialysis systems. Nephrology 2010, 15, 406-411.

(7) Lehmann, H. D.; Marten, R.; Gullberg, C. A. How to catch urea? Considerations on urea removal from hemofiltrate. Artif. Organs 1981, $5,278-85$.

(8) Urbańczyk, E.; Sowa, M.; Simka, W. Urea removal from aqueous solutions-a review. J. Appl. Electrochem. 2016, 46, 1011-1029.

(9) Roberts, M. The regenerative dialysis (REDY) sorbent system. Nephrology 1998, 4, 275-278.

(10) Gura, V.; Rivara, M. B.; Bieber, S.; Munshi, R.; Smith, N. C.; Linke, L.; Kundzins, J.; Beizai, M.; Ezon, C.; Kessler, L.; Himmelfarb, $\mathrm{J}$. A wearable artificial kidney for patients with end-stage renal disease. JCI Insight 2016, 1, 15.

(11) Cheng, Y.-C.; Fu, C.-C.; Hsiao, Y.-S.; Chien, C.-C.; Juang, R.-S. Clearance of low molecular-weight uremic toxins p-cresol, creatinine, and urea from simulated serum by adsorption. J. Mol. Liq. 2018, 252, 203-210.

(12) Wernert, V.; Schäf, O.; Ghobarkar, H.; Denoyel, R. Adsorption properties of zeolites for artificial kidney applications. Microporous and Mesoporous Mater. 2005, 83, 101-113.

(13) Poss, M. J.; Blom, H.; Odufu, A.; Smakman, R. Macromolecular ketoaldehydes. U.S. Patent 6,861,473 B2, 2005.

(14) Smakman, R. Macromolecular carbonyl groups containing material suitable for use as sorbent for nitrogen compounds. U.S. Patent 4,897,200, 1990.

(15) Wong, R. J. Materials for removal of toxins in sorbent dialysis and methods and systems using same. U.S. Patent 2014/0,336,568 A1, 2014.

(16) Eisen, M. S. Urea sorbent. U.S. Patent 8,220,643 B2, 2014.

(17) Shimizu, T.; Fujishige, S. A newly prepared surface-treated oxystarch for removal of urea. J. Biomed. Mater. Res. 1983, 17, 597612.

(18) Deepak, D. Evaluation of adsorbents for the removal of metabolic wastes from blood. Med. Biol. Eng. Comput. 1981, 19, 701706.

(19) Smakman, R.; Vandoorn, A. W. J. Urea removal by means of direct binding. Clin. Nephrol. 1986, 26, S58-S62.

(20) Roberts, C. W. The synthesis and properties of ninhydrin ureide. J. Biol. Chem. 1943, 150, 471-476.

(21) Shapiro, R.; Chatterjie, N. Cyclization reactions of ninhydrin with aromatic amines and ureas. J. Org. Chem. 1970, 35, 447-450.

(22) Jong, J. A. W.; Moret, M.-E.; Verhaar, M. C.; Hennink, W. E.; Gerritsen, K. G. F.; van Nostrum, C. F. Effect of substituents on the reactivity of ninhydrin with urea. ChemistrySelect 2018, 3, 1224-1229.

(23) Kostyanovsky, R. G.; Shtamburg, V. G.; Shishkin, O. V.; Zubatyuk, R. I.; Shtamburg, V. V.; Anishchenko, A. A.; Mazepa, A. V. Pyramidal nitrogen in the crystal of $\mathrm{N}$-[(benzoyl)(hydroxy)methyl]N-benzyloxy-N '-(2-bromophenyl)urea. Mendeleev Commun. 2010, 20, 167-169.

(24) Arnold, Z.; Buděšínský, M.; Pánková, M. Reactivity of triformylmethane. I. Reactions of triformylmethane with selected types of amino compounds. Collect. Czech. Chem. Commun. 1991, 56, 1019-1031.

(25) Gadda, G.; Negri, A.; Pilone, M. S. Reaction of phenylglyoxal with arginine groups in $\mathrm{D}$-amino-acid oxidase from Rhodotorula gracilis. J. Biol. Chem. 1994, 269, 17809-17814.

(26) Bohren, K. M.; von Wartburg, J. P.; Wermuth, B. Inactivation of carbonyl reductase from human brain by phenylglyoxal and 2,3butanedione: A comparison with aldehyde reductase and aldose reductase. Biochim. Biophys. Acta 1987, 916, 185-192.

(27) Zenkova, E. A.; Degterev, E. V. Optimization of ninhydrin reagent synthesis from 1,2,3,4-tetrahydro-1,4-dioxo-2,2,3,3-tetrahydroxynaphthalene (oxolin) and possible applications. Pharm. Chem. J. 2000, 34, 135-137.
(28) Ramakrishna, S.; Benjamin, W. B. Evidence for an essential arginine residue at the active site of ATP citrate lyase from rat liver. Biochem. J. 1981, 195, 735-743.

(29) Koissi, N.; Neuvonen, K.; Munter, T.; Kronberg, L.; Lönnberg, $\mathrm{H}$. Condensation of triformylmethane with guanosine. Nucleosides, Nucleotides Nucleic Acids 2006, 20, 1761-1774.

(30) Clayden, J.; Warren, S.; Greeves, N.; Wothers, P. Organic Chemistry; Oxford University Press: 2000, pp 349.

(31) Tserng, K. Y.; Kalhan, S. C. Gas chromatography/mass spectrometric determination of [15N]urea in plasma and application to urea metabolism study. Anal. Chem. 1982, 54, 489-491.

(32) Maltsev, O. V.; Pöthig, A.; Hintermann, L. Synthesis of Soai aldehydes for asymmetric autocatalysis by desulfurative crosscoupling. Org. Lett. 2014, 16, 1282-1285.

(33) Rubin, M. B. Chemistry of Vicinal Polyketones. Chem. Rev. 1975, 75, 177-202.

(34) Alvarez, M.; Fernández, D.; Joule, J. A. Synthesis of 1,2dihydropyrrolo[1,2-c]pyrimidin-1-ones. J. Chem. Soc., Perkin Trans. 1 1999, 249-256.

(35) Frisch, M.J.; Trucks, G.W.; Schlegel, H.B.; Scuseria, G.E.; Robb, M.A.; Cheeseman, J.R.; Scalmani, G.; Barone, V.; Mennucci, B.; Petersson, G.A.; Nakatsuji, H.; Caricato, M.; Li, X.; Hratchian, H.P.; Izmaylov, A.F.; Bloino, J.; Zheng, G.; Sonnenberg, J.L.; Hada, M.; Ehara, M.; Toyota, K.; Fukuda, R.; Hasegawa, J.; Ishida, M.; Nakajima, T.; Honda, Y.; Kitao, O.; Nakai, H.; Vreven, T.; Montgomery, J.A., Jr.; Peralta, J.E.; Ogliaro, F.; Bearpark, M.; Heyd, J.J.; Brothers, E.; Kudin, K.N.; Staroverov, V.N.; Kobayashi, R.; Normand, J.; Raghavachari, K.; Rendell, A.; Burant, J.C.; Iyengar, S.S.; Tomasi, J.; Cossi, M.; Rega, N.; Millam, N.J.; Klene, M.; Knox, J.E.; Cross, J.B.; Bakken, V.; Adamo, C.; Jaramillo, J.; Gomperts, R.; Stratmann, R.E.; Yazyev, O.; Austin, A. J.; Cammi, R.; Pomelli, C.; Ochterski, J. W.; Martin, R.L.; Morokuma, K.; Zakrzewski, V.G.; Voth, G.A.; Salvador, P.; Dannenberg, J.J.; Dapprich, S.; Daniels, A.D.; Farkas, Ö.; Foresman, J.B.; Ortiz, J.V.; Cioslowski, J.; Fox, D.J. Gaussian 09, Revision A.02; Gaussian, Inc.: Wallingford, CT, 2009.

(36) Gill, G.B.; Idris, M.S.H.; Kirollos, K.S. Ene reactions of indane1, 2, 3-trione (a super-enophile) and related vicinal tricarbonyl systems. J. Chem. Soc.-Perkin Trans. 1 1992, 2355-2365.

(37) Shoppee, C. W. 59. $1: 2: 3$-Triketotetramethylcyclopentane: A blue triketone. J. Chem. Soc. 1936, 269-274.

(38) Liang, Y.-F.; Li, X.; Wang, X.; Zou, M.; Tang, C. H.; Liang, Y.; Song, S.; Jiao, N. Conversion of simple cyclohexanones into catechols. J. Am. Chem. Soc. 2016, 138, 12271-12277.

(39) Krief, P.; Becker, J. Y.; Ellern, A.; Khodorkovsky, V.; Neilands, O.; Shapiro, L. s-Indacene-1,3,5,7(2H,6H)-tetraone ('Janusdione') and 1,3-dioxo-5,6-indanedicarboxylic acid: Old and new 1,3indandione Derivatives. Synthesis 2004, 2004, 2509-2512.

(40) Marminon, C.; Nacereddine, A.; Bouaziz, Z.; Nebois, P.; Jose, J.; Le Borgne, M. Microwave-assisted oxidation of indan-1-ones into ninhydrins. Tetrahedron Lett. 2015, 56, 1840-1842.

(41) Buděśínský, M.; Fiedler, P.; Arnold, Z. Triformylmethane: An efficient preparation, some derivatives, and spectra. Synthesis 1989, $1989,858-860$. 